УДК 614.84:664.72

\title{
ПІДПРИЄМСТВА ПО ЗБЕРІГАННЮ ЗЕРНА: РИЗИК ВИНИКНЕННЯ ПОЖЕЖ
}

С.М. Неменуща*, канд. с.-е. наук, О.О. Фесенко, В.М. Лисюк, канд. техн. наук, доцент Одеська національна академія харчових технологій, Україна

ІНФОРМАЦІЯ ПРО СТАТТЮ
Надійшла до редакції: 16.03.2019
Пройшла рецензування: 25.04.2019
КЛЮЧОВІ СЛОВА:
зернопереробна галузь, елеватори,
пожежна і вибухопожежна безпека,
ідентифрікація місць локалізації, ризик

\begin{abstract}
АНОТАЦІЯ
В роботі проведено аналіз пожежної та вибухопожежної безпеки на зернових елеваторах в Україні за останні 11 років. Встановлено, що на зернових елеваторах починаючи з 2014 року щорічно спостерігається збільшення кількості випадків виникнення пожеж. Якщо у 2014 та 2016 роках зафіксовано відповідно по 3 пожежі, то у 2018 році зафіксовано вже 15. Тільки за 2 місяці 2019 року про такі надзвичайні ситуації на елеваторах повідомлялося 4 рази. Ідентифріковано місця локалізації ризику виникнення пожеж та вибухів на підприємствах. Локалізація пожеж відбувалася у 56,8\% випадках в зернових сушарках. На другому місці фрігурують пожежі у складах - 18,2\%. Однакову кількість пожеж, по 4,5\% від частоти виникнення, зафіксовано у норіях, на транспортних галереях та на трансформаторних підстанціях. Інколи, 3 імовірністю до 2,4\% за кожним з випадків, загоряння були в результаті удару блискавки та чинників «людського фактору» (порушення технологічного регламенту, правил проведення вогневих робіт, підпалу). Проведена оцінка ризику виникнення пожеж на зернових елеваторах статистичним методом. Встановлено, що імовірність пожеж за останні 11 років становила $R=18,9 \times 10^{-4}$ на зерносушарках, a у складах - $R=6,05 \times 10^{-4}$. Ризик виникнення пожеж у норіях, на транспортних галереях та на трансформаторних підстанціях оцінювався відповідно $\mathrm{R}=1,5 \times 10^{-4}$. Якщо причинами виникнення пожеж був «людський фактор», а саме порушення технологічного регламенту, правил проведення вогневих робіт та у результаті підпалу, то кожного разу ризик становив $\mathrm{R}=7,5 \times 10^{-5}$. 3 метою забезпечення пожежної та вибухопожежної безпеки на елеваторах пропонується: проводити заміну, реконструкцію або переоснащення технологічного обладнання, машин, механізмів тощо; перевіряти наявність розроблених технічних проектів, технологічних регламентів, іншої технічної документації для робіт підвищеної небезпеки, справності обладнання, інструменту, захисних пристроїв небезпечних зон машин і механізмів, пускових, запобіжних, гальмових і очисних пристроїв, систем блокування та сигналізації, вентиляції та освітлення, знаків безпеки, первинних засобів пожежогасіння, проведення на підприємствах паспортизації будівель, споруд, інженерних мереж тощо.
\end{abstract}

Постановка проблеми. На сьогоднішній день однією 3 найбільших галузей агропромислового комплексу України $\epsilon$ зернопереробна промисловість. Ї̈̈ підприємства забезпечують населення борошном і крупами, а відходи використовуються для виробництва комбікормів. Суб'єктами зберігання зерна для переробки, відповідно до статті 7 Закону України «Про зерно та ринок зерна в Україні» [1], є зернові склади (елеватори, хлібні бази, хлібоприймальні, борошномельні i комбікормові підприємства).

Серед підприємств по зберіганню зерна левова частка належить елеваторам, в тому числі КХП та ХПП. На сьогоднішній день таких підприємств понад 1200 [2]. Їх сфера діяльності - приймання, зберігання, доведення до базисних кондицій (очищення та сушіння), відвантаження зерна. За видами зернові елеватори бувають: заготівельні (лінійні); виробничі (біля млинів, комбікормових заводів); перевалочні (базисні та портові); фондові (для тривалого зберігання державного зернового резерву). Основна маса зерна на елеваторах зберігається в залізобетонних спорудах за підлоговою технологією. Переважну більшість 3 них збудовано ще за часів СРСР. Технічна база таких підприємств нині фізично й морально застаріла [3]. Тому об'єкти створюють реальну загрозу виникнення надзвичайної ситуації i $\epsilon$ потенційно небезпечними виробництвами відповідно до визначень [4].

Кожного року у світі на зернопереробних підприємствах відбувається 400-500 вибухів і 
пожеж. В Україні щорічно фіксується близько 10 первинних пилових вибухів на таких об'єктах. Вибухи приносять великий економічний збиток, призводять до руйнування підприємств і загибелі людей [5].

За умов фізичного зношення обладнання зернових елеваторів питання пожежної та вибухопожежної безпеки на сьогоднішній день $\epsilon$ актуальними. Велике значення має і важкість наслідків від надзвичайних ситуацій для підприємств. Отже, оцінка ризику виникнення надзвичайних ситуацій внаслідок пожеж i вибухів на зернових елеваторах та їх унеможливлення на сьогоднішній день $є$ дуже важливими умовами для їх сталої роботи.

Аналіз останніх досліджень $і$ публікацій. Проаналізувавши літературні джерела щодо ризику виникнення пожеж на елеваторах, встановили, що останні 11 років дуже мало приділяли уваги цим питанням. В більшості випадків дослідження проводили 3 питань загального стану пожежної безпеки [6], покращення економічних та організаційних [7, 8] і екологічних [9] чинників зернопереробної галузі. Вивченням вибухобезпеки на підприємствах займався N. Thomson [10]. Оцінці пожежного ризику для споруд виробничого призначення присвячені праці [11-16]. Щодо об'єктів зберігання та переробки зерна, то ідентифікація джерел ризику виникнення пожеж здійснювалася Разиньковим І.В. [17], а вибухобезпеки - Пунковим С.П. [18]. Пожежна безпека зерносушарок висвітлювалася у роботі Фесенко О.О., Лисюк В.М. [19]. Питанню автоматизації процесів спостереження за вибухопожежною безпекою силосів і силосних корпусів зернових та зернопереробних підприємств присвячена робота Волкова B.С.[20]. Питанням оцінки впливу пожежного ризику на величину збитків від пожежі в приміщеннях різних об' єктів присвячена робота Гуліда Е.М. [23].

Чинниками займання пилоповітряних сумішей на елеваторних підприємствах, за літературними джерелами [21], є електрозварювальні та інші вогневі роботи $(35 \%)$, самозаймання або займання зерна або зернових продуктів у силосах (15\%), несправність технологічного i транспортного обладнання $(25 \%)$, порушення правил проведення сушіння зерна (20\%). Найбільша кількість первинних вибухів відбувається у силосах та бункерах (49\%), менше - в норіях (26\%), аспіраційних системах $(10 \%)$ та зерносушарках $(10 \%)$ і у $5 \%$ випадків місця вибуху невстановлені.

Тому результати дослідження можуть використовуватися для планування заходів $\mathrm{i}$ засобів підвищення стійкості роботи підприємств галузі та уточнення довгострокових планів локалізації та ліквідації надзвичайних ситуацій на зернових елеваторах.

Постановка задачі та ї̈ розв'язання. Метою дослідження $\epsilon$ аналіз пожежної та вибухопожежної безпеки на зернових елеваторах в Україні за останні 11 років.

Об'єкт дослідження - ідентифікація місць локалізації ризику виникнення пожеж та вибухів на підприємствах зернопереробної галузі джерел - елеваторах.

Предмет дослідження - чинники, що впливають на ризик виникнення пожеж на зернових елеваторах.

Нами було проведено дослідження інформаційних джерел щодо виникнення пожеж на зернових елеваторах в Україні за остання 11 років (рис. 1) та встановлення місць їх локалізації (рис. 2) за даними сайту Elevatorist.com [2].

Встановлено, що на зернових елеваторах починаючи з 2014 року щорічно спостерігається збільшення кількості випадків виникнення пожеж. Так, якщо у 2014 та 2016 роках їх було відповідно по 3, то у 2018 році - 15. Тільки за 2 місяці 2019 року зафіксовано вже 4 надзвичайні ситуації з виникненням пожеж на елеваторах.

За місцями локалізації найчастіше, а саме у $56,8 \%$ випадках, мали місце пожежі у зернових сушарках. На другому місці фігурують пожежі у складах - 18,2\%. У норіях, на транспортних галереях та на трансформаторних підстанціях частота виникнення пожеж була на рівні 4,5\%. Інколи, 3 імовірністю до $2,4 \%$ за кожним 3 випадків, причинами пожеж були удари блискавки та чинники «людського фактору» (порушення технологічного регламенту, правил проведення вогневих робіт, підпалу). 


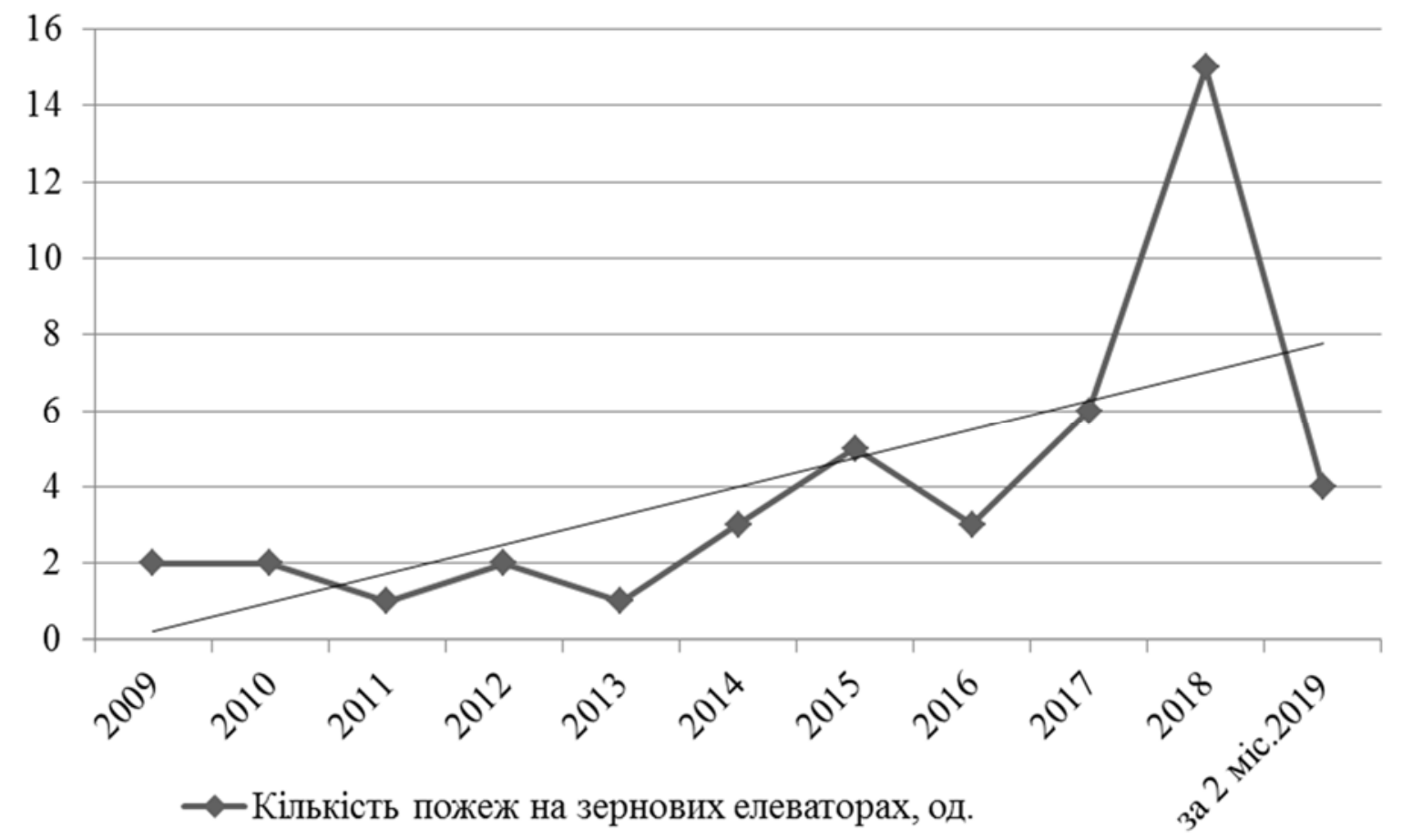

Рис. 1. Розподіл кількості пожеж на зернових елеваторах по роках (2009-2019рр.)

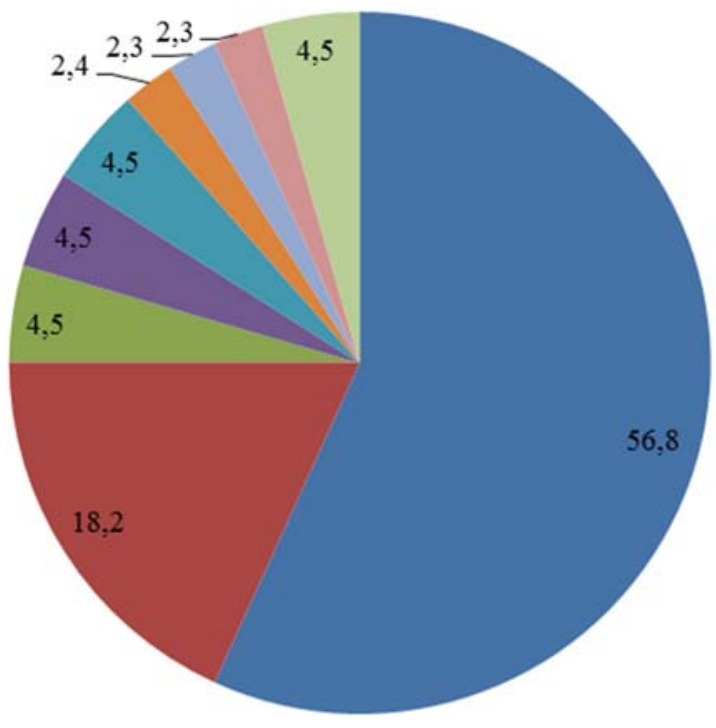

Основні місця виникнення пожеж (\%):

ш Зерносушарка

- Склад

- Норія

- Транспортна галерея

- Трансформаторна підстанція

ш Порушення технологічного регламенту

шлискавка

шорушення правил проведення вогневих робіт

підпал

Рис. 2. Розподіл пожеж за місцями локалізації на зернових елеваторах, \% (2009-2019рр.)

Проаналізувавши отримані дані за останні 11 років 3 огляду на місця локалізації пожеж встановлено, що найбільш небезпечним i шкідливим фактором на зернових елеваторах, який може призвести до пожеж і вибухів, $\epsilon$ підвищений вміст пилу у повітрі робочої зони. Зерновий пил утворюється під час здійснення технологічних операцій 3 приймання, переміщення, очищення та відпуску зерна, а у сушарках - під час сушки зерна.
Велика кількість пилу утворюється при розвантаженні зерна автомобільним i залізничним транспортом за допомогою самопливу - переміщення під дією сили ваги. В свою чергу, завантаження автомобілів і вагонів також здійснюють цим же способом. Перетікання зерна починається від місця розвантаження до норій і транспортерів. I на виході із самопливу виділяється велика кількість пилу. Аналогічні проблеми характерні також при розвантаженні барж і суден. 
Органічний пил утворюється і в результаті взаємного тертя оболонок зерна, тертя зерна робочими органами машин та тертя зерна по стінках самопливних труб і бункерів. Велика кількість машин і механізмів сприяє утворенню небезпечного чинника.

Так, при роботі норій спостерігається дуже запилена атмосфера усередині норійних труб. Суміщене переміщення зерна та потоку повітря, що захоплюється ним, за дією аналогічно вентилятору, який працює в режимі нагнітання та всмоктування. Якщо немає герметичності обладнання i позитивний тиск у башмаці, голівці або норійної трубі, то утворюється і джерело пилу.

Стрічкові конвеєри являють собою серйозні джерела поширення пилу, особливо при їх розвантаженні i завантаженні. Причому конвеєри відкритого виконання $€$ найбільш сильним джерелом пиловиділення через рух потоку повітря.

Самопливи і жолоби також можуть бути джерелами пилу за рахунок внутрішньої турбулентності. При цьому довгі ділянки самопливів, по яких переміщається зерно 3 високою швидкістю і 3 великою кількістю повітря, яке захоплюється зерном, більш небезпечне джерело пилу, аніж короткі самопливи і жолоби.

Проблематичними $є$ системи зважування 3 надваговими i підваговими вантажоприймальними бункерами, бо вони по черзі завантажуються i розвантажуються. Бункери $є$ особливо небезпечними місцями. Вони являють собою закриті конструкції і під час заповнення в них утворюється висока концентрація зваженого пилу.

Таким чином, всередині зерноочисних технологічних машин, бункерів, силосів та транспортного обладнання (норії) постійно утворюється пилоповітряна суміш, концентрація якої часто перевищує вибухонебезпечну межу. Повністю виключити утворення таких сумішей неможливо, тому що це обумовлено технологією зерноочищення.

Запиленість $є$ типовою для багатьох галерей елеваторів старої будівлі. Це результат недостатньої аспірації силосів i розвантажувальних візків. Після розвантаження силосу на стінах і стелі звичайно осідає шар пилу.

Промисловий пил - це сукупність тонкоподрібнених частинок твердої речовини, які перебувають як у завислому (аерозоль) стані, так і у вигляді осадку (аерогель). Відповідно до санітарних норм [29] вміст зернового пилу в повітрі виробничих приміщень визначається показником гранично допустимої концентрації (ГДК) i не повинен перевищувати середньодобової норми $0,03 \mathrm{mг} / \mathrm{m}^{3}$. Важливою властивістю окремих видів пилу, таких як зерновий, фуражний, борошняний та деяких інших, $є$ вибуховість. Пил на зернових підприємствах переважно перебуває у стані аерозолю. В такому стані утворюються потужні заряди, які можуть викликати іскри 3 великою енергією - пилові блискавки, що є достатнім для займання пилоповітряної суміші. Таке займання відбувається всередині замкнутих просторів обладнання, бункерів, силосів. Кількість високотемпературних газоподібних продуктів, які утворюються під час горіння даної суміші, та тиск напряму залежать від концентрації пилу у замкнутому просторі. Гарячі газоподібні продукти вибуху, стикаючись з повітрям, часто займаються, що може призвести і до пожежі. Найменшу та найбільшу концентрацію горючих парів, газів або пилу в повітрі, що утворюють вибухову суміш, називають відповідно нижньою і верхньою межами вибуховості. Так, мінімальна концентрація пилу, за якої може утворитися вибух, становить для млинового сірого пилу $-17,6$ г $/ \mathrm{M}^{3}$, пилу фуражного жита $27,7 \Gamma / \mathrm{M}^{3}[30]$.

Промисловий пиловий вибух виникає через технічні та організаційні порушення при проведенні технологічних процесів, під час експлуатації, ремонті технологічного та транспортного обладнання, будівель і споруд. органічного пилу, який може створювати вибухонебезпечне середовище.

Пиловий вибух відноситься до процесів вибухового горіння, які не можливо контролювати. Це швидке згоряння пилоповітряної суміші 3 виділенням газоподібних продуктів, які можуть виконувати роботу при розширенні, тобто руйнувати все те, що знаходиться в осередку і зоні вибуху. Всередині замкнутого простору при вибухах створюється такий статичний тиск, який у 12,5 разів перевищує показники імовірності руйнування залізобетонної плити.

До потенційно небезпечних джерел спалаху пилоповітряних сумішей відносяться насамперед електроустановки, несправне обладнання, проведення вогневих робіт. Особливістю зберігання зерна $є$ самозаймання.

Джерелом займання пилоповітряної суміші можуть бути розряди статичної електрики, які накопичуються на ізольованих частинах обладнання, самопливних трубах, ременях приводу тощо. 
Зерно та зернопродукти під час зберігання у силосах, бункерах та складах внаслідок біологічних процесів, що відбуваються всередині ї маси, та невеликої теплопровідності можуть самозігріватися. При цьому температура всередині зернових мас зростає до температури самозаймання.

Щодо оцінки ризику виникнення надзвичайних ситуацій, то найбільш розповсюдженим і прийнятим поняттям ризику у сучасній теорії і практиці безпеки життєдіяльності є визначення, що ризик - це частота реалізації небезпеки.

Серед великої кількості запропонованих методичних підходів до визначення ризику науковці виділяють основні: інженерний, модельний, експертний, соціологічний, статистичний, комплексний (комбінований).

За статистичним методом ризик обчислюється за формулою: $\mathrm{R}=\mathrm{n} / \mathrm{N}$, де $\mathrm{R}$ - ризик за певний період часу; $\mathrm{n}$ - кількість фактичних проявів небезпеки за цей період; $\mathrm{N}$ - теоретична можлива кількість небезпек для даного виду діяльності чи на об'єкті.

У своїх дослідженнях ми використовували оцінку ризику виникнення пожеж на зернових елеваторах статистичним методом. Нами встановлено, що імовірність виникнення пожеж за останні 11 років щороку становила $\mathrm{R}=18,9 \times 10^{-4}$ на зерносушарках, а у складах $\mathrm{R}=6,05 \times 10^{-4}$. Ризик виникнення пожеж у норіях, на транспортних галереях та на трансформаторних підстанціях становив відповідно $\mathrm{R}=1,5 \times 10^{-4}$ за кожним 3 випадків. Якщо причинами виступали чинники «людського фактору», а саме порушення технологічного регламенту, правил проведення вогневих робіт та у результаті підпалу, то ризик становив $\mathrm{R}=7,5 \times 10^{-5}$.

Для будь-якого підприємства ризик від виникнення пожеж відповідно до рекомендацій Всесвітньої організації охорони здоров'я [24] та постанови КМУ № 306 [25] класифікують як незначний $\mathrm{R} \leq 10^{-6}$, середній $\mathrm{R}=10^{-6}-10^{-5}$, високий (терпимий) $\mathrm{R}=5 \times 10^{-5}-5 \times 10^{-4}$ та неприйнятний $\mathrm{R}>5 \times 10^{-4}$.

3 огляду на отримані розрахунки величини ризику виникнення пожеж на зернових елеваторах та порівнявши їх значення 3 величинами відповідно до класифікації ризику $[24,25]$ можна зробити висновок, що ризик виникнення пожеж знаходиться у межах від високого (терпимого) до неприйнятного. Такі умови не сприяють стійкій роботі галузі в цілому і потребують вжиття відповідних заходів 3 покращення роботи на підприємствах. Але величина пожежного ризику вказує тільки на міру можливої реалізації пожежної небезпеки. Умовами забезпечення безпеки у разі виникнення пожежі $\epsilon$ оперативна евакуація людей, швидкий виклик пожежно-рятувальних підрозділів і стрімке реагування добровільної пожежної дружини підприємства.

Превентивними заходами попередження пожеж та інших надзвичайних ситуацій техногенного характеру в Україні для об'єктів підвищеної небезпеки відповідно до [28] $є$ аналіз небезпеки та умов виникнення аварій, оцінка ризику виникнення аварій, аналіз умов і оцінка ймовірності розвитку аварій, оцінка ймовірності наслідків аварій. 3 цією метою для підприємств пропонується застосування окремих методів, таких як:

- дерево «відмов»;

- аналіз видів і наслідків відмов;

- обробка статистичних даних про аварійність технологічної системи, що відповідають специфіці об'єктів підвищеної небезпеки чи виду діяльності;

- «що буде, якщо?»;

- «перевірочний лист»;

- аналіз експлуатаційної небезпеки (HAZOP - аналіз Hazard and Operability Study );

- експертні оцінки імовірності виникнення події.

На підставі аналізу потенціальних відхилень можна виявляти небезпечні події, які ініціюють виникнення та розвиток аварій на кожному об'єкті. Для оцінки ризику (імовірності) виникнення аварій кожної події виконується оцінка імовірності іiі реалізації протягом одного року. Якщо імовірність виникнення аварії $\epsilon$ неприйнятною величиною, то відшукуються рішення щодо ії зниження. На сьогоднішній день проходить гармонізація вітчизняної нормативно-технічної бази 3 європейською. Розроблено ДСТУ ISO/TR 16732-3 (ISO/TR16732-3:2013, IDT) Інжиніринг пожежної безпеки. Оцінювання пожежного ризику. Частина 3. Приклад промислового підприємства [31] та ДСТУ EN ISO 19353 (EN ISO 19353:2016, IDT, ISO 19353:2015, IDT) Безпечність машин. Запобігання пожежі та протипожежний захист [32].

Висновки. Проаналізувавши ризики пожежної та вибухопожежної безпеки на підприємствах зберігання зерна - елеваторах встановили високу імовірність виникнення пожеж - від 7,5×10 $0^{-5}$ до $18,9 \times 10^{-4}$. Уточнені дані щодо місць локалізації пожеж - найбільш небезпечними є зерносушарка та склади. Нами охарактеризовані небезпечні та шкідливі 
фактори, які можуть вплинути на частоту реалізації небезпеки. Така ситуація свідчить про зношеність технологічного обладнання зерносушильних комплексів та недостатній рівень контролю за зберіганням зерна на складах підприємств.

За результатами дослідження 3 метою забезпечення пожежної та вибухопожежної безпеки на елеваторах пропонується:

- регулярно проводити превентивний аналіз небезпеки та умов виникнення аварій;

- проводити заміну, реконструкцію або переоснащення технологічного обладнання, машин, механізмів тощо;

- регулярно проводити навчання та перевірку знань 3 питань пожежної безпеки та охорони праці посадовим особам та працівникам, які виконують роботи підвищеної небезпеки;

відповідальними за виконання конкретного виду робіт підвищеної небезпеки призначати посадових осіб, які пройшли навчання та перевірку знань 3 питань пожежної безпеки та охорони праці;

- перевіряти наявність розроблених технічних проектів, технологічних регламентів, іншої технічної документації для робіт підвищеної небезпеки, справності обладнання, інструменту, захисних пристроїв небезпечних зон машин і механізмів, пускових, запобіжних, гальмових i очисних пристроїв, систем блокування та сигналізації, вентиляції та освітлення, знаків безпеки, первинних засобів пожежогасіння, проведення на підприємствах паспортизації будівель, споруд, інженерних мереж;

експлуатацію електроустановок, електрообладнання забезпечувати відповідно до вимог безпеки;

- за графіком проводити профілактичні виміри опору заземлюючих пристроїв електроустановок, ізоляції кабелів, перевірку стану безпеки електроустановок;

- забезпечити підприємства всіма необхідними засобами пожежогасіння;

- виконання робіт в силосах, бункерах та інших закритих ємкостях здійснювати тільки після оформлення наряд-допуску;
- працівників підприємств, що залучаються до виконання небезпечних робіт, забезпечувати засобами захисту i пристосуваннями для безпечного проведення робіт;

- транспортне обладнання для переміщення зерна (норії, транспортери, конвеєри тощо) має бути обладнане справними засобами й елементами, що забезпечують безпеку під час експлуатації (датчики контролю швидкості, ручні пристрої відключення транспортеру, датчики контролю температури, стрічки, датчики контролю навантаження, пристрої, що запобігають зворотному ходу стрічки або іiі пробуксовці), а також системами аспірації, що синхронізуються 3 пусковими пристроями обладнання і забезпечені пилоуловлювальними пристроями (рукавними фільтрами, пиловими камерами тощо), що унеможливлюють вихід запиленого повітря в робоче приміщення складу або елеватора;

- вивішувати таблички попередження на пускових пристроях, вхідних дверях щодо категорії вибухопожежонебезпеки та класу зони по електробезпеці;

- перевіряти наявність та справність засобів дистанційного контролю температури зерна в силосах та бункерах;

- дотримуватися графіків прибирання пилу у виробничих приміщеннях;

- вогневі роботи проводити відповідно до вимог НАПБ В.01.057-2006/200 [27];

- на дахах складських приміщень облаштовувати блискавкозахист;

- коригувати плани локалізації і ліквідації аварійних ситуацій та аварій;

- щоквартально проводити тренувальні навчання 3 персоналом та відпрацювання можливі дії працівників у разі виникнення надзвичайних ситуацій техногенного характеру;

- не допускати роботу технологічного обладнання у вибухопожежонебезпечних та пожежонебезпечних приміщеннях у разі несправних або відключених пиловідсмоктуючих, пиловловлюючих та інших пристроїв систем вентиляції. 


\section{СПИСОК ЛІТЕРАТУРИ}

1. Закон України «Про зерно та ринок зерна в Україні» від 04.07.2002 №37-IV [Електронний ресурс]. - Режим доступу: http://www.zakon.4.rada.gov.ua

2. Elevarist.com [Електронний ресурс]. - Режим доступу: http:// elevarist.com

3. Станкевич Г.Н. Современное состояние рынка зернохранилищ. // Зернові продукти і комбікорми. 2010. - №3. - C. 34-40.

4. «Методика ідентифікації потенційно небезпечних об'єктів» наказ № 98 від 23.02.2006 р. Міністерства України з питань НС та у справах захисту населення від наслідків Чорнобильської катастрофи.

5. [Електронний ресурс]. - Режим доступу: https://loretest.com/blog/2018/11/07/.

6. Статистика пожеж та їх наслідків в Україні за 20132016 роки: Статистичний збірник аналітичних матеріалів. За загальною редакцією В.С. Кропивницького. - К.:УкрНДІЦЗ, - 2018. - 100 с.

7. Стретович О.А. Тенденції роботи зернопереробних підприємств України.// Економіка харчової промисловості. - т. 8. - вип. 4. - 2016. - С. 46-50.

8. Колодійчук В.А. Галузеве позиціонування зернопродуктового підкомплексу АПК України. // Економічний часопис - XXI. - 9-10(1). - 2014. - С. 4548.

9. Зацеркляний М.М. Утворення пилу на підприємствах галузі хлібопродуктів $\mathrm{i}$ зменшення пиловиділення./Науково-технічний журнал «Техногенно-екологічна безпека». - 2018. - №3(1). - С. $16-20$.

10. Thomson N. Fire Hazards in Industry. - 2001. - 176 p.

11. Д'яконов В.І., Кусов О.В., Фесенко Г.В., Білим П.А., Миронович В.В. Оцінка пожежного ризику для споруд виробничого призначення. // Вісник Харківського національного технічного університету сільського господарства ім. П. Василенка. - 2014. - вип. 148. - С. 514-519.

12. Гуліда Е.М., Мовчан I.О. Оцінка пожежного ризику для споруд виробничого призначення. //Науковий вісник ЛНТУ України. - 2012. - вип. 22.9. - С. 118-128.

13. Мовчан І.О, Гуліда Е.М. Вибір моделі визначення пожежного ризику для об'єктів господарювання. //Науковий вісник ЛНТУ України. - 2012. - вип. 22.13. - C. 364-370.

14. Смельяненко С.О., Кузик А.Д. Ризик як характеристика стану пожежної безпеки.// Пожежна безпека. - Львів: ЛДУ БЖД. - 2011. - вип. 18. - С. 101-106.

15. Вогман А.П., Хрюкин А.В. Пожарная опасность отложений на оборудовании, в вентиляционных системах и местных отосах объектов переработки и хранения материалов растительного происхождения. [Електронний ресурс]. - Режим доступу: https://cyberleninka.ru/article/n/pozharnaya-opasnostotlozheniy-na-oborudovanii-v-ventilyatsionnyh-sistemahi-mestnyh-otsosah-obektov-pererabotki-i-hraneniyamaterialov-1

16. Азаров В.Н., Колесников В.Г. Оценка взрывопожароопасности предприятий по хранению и переработке зерна. // Пожаровзрывобезопасность. 2003. - №1. - C. 51-53.

17. Разиньков И.В. Специфические факторы пожарных рисков на предприятиях пищевой промышленности Воронежской области. [Електронний ресурс]. - Режим доступу: https://cyberleninka.ru/article/n/spetsificheskiefaktory-pozharnyh-riskov-na-predpriyatiyah-pischevoypromyshlennosti-voronezhskoy-oblasti

18. Пунков С.П., Ким Л.В., Фейденгольд В.Б. Проектирование элеваторов и хлебоприемных предприятий с основами САПР: Учебник /Под ред. С.П. Пункова. - Воронеж: Издательство Воронежского университета, 1996. - $284 \mathrm{c}$.

19. Фесенко О.О., Лисюк В.М. Проблеми пожежної безпеки зерносушарок. // Матеріали VII Всеукраїнської науково-практичної конференції 3 міжнародною участю «Надзвичайні ситуації: безпека та захист». Черкаси: ЧІПБ ім. Героїв Чорнобиля НУЦЗ України. 2017. - С. 73-74.

20. Волков В.Э. Система поддержки принятия решений по вопросам взрывобезопасности силосов и силосних корпусов зерновых и зерноперерабатывающих предприятий.// Автоматика. - Львів. - 2011. - С. 335336. [Електронний ресурс]. - Режим доступу: http:// ena.lp.edu.ua

21. Теплов А.Ф. Охрана труда в отрясли хлебопродуктов: М,: Агропромиздат, 1990.- 255 с.

22. [Електронний pесурс]. - Режим доступу: http://www.eco.ck.ua/

docs/Perelik\%20rechovyn,\%20klas\%20nebezpeky.doc

23. Гуліда Е.М. Вплив пожежного ризику на величину збитків віл пожежі в приміщеннях різних об'єктів. //Пожежна безпека: збірник наукових праць ЛДУ БЖД. - 2016. - №28. - C. 36-42.

24. Бєгун В.В. Безпека життєдіяльності: Навчальний посібник/В.В. Бєгун, I.М. Науменко. - К.:2004. - 328 с.

25. Постанова Кабінету Міністрів України від 29 лютого 2012 p. №306. - K. -3 c.

26. НАПБ А.01.001-2014. Правила пожежної безпеки в Україні.

27. НАПБ В.01.057-2006/200. Правила пожежної безпеки в агропромисловому комплексі України.

28. «Методика визначення ризиків та їх прийнятних рівнів для декларування безпеки об'єктів підвищеної небезпеки» затверджена наказом № 637 від 4 грудня 2002 р. Міністерства праці та соціальної політики України.

29. ГОСТ 12.1.005-88 «Общие санитарно-гигиенические требования к воздуху рабочей зоны».

30. Штокман Е.А. Вентиляция, кондиционирование и очистка воздуха на предприятиях пищевой промышленности. [Текст]/Е.А. Штокман - М.:АCВ, 2001. $-564 \mathrm{c}$.

31. ДСТУ ISO/TR 16732-3 (ISO/TR16732-3:2013, IDT) Інжиніринг пожежної безпеки. Оцінювання пожежного ризику. Частина 3. Приклад промислового підприємства.

32. ДСТУ EN ISO 19353 (EN ISO 19353:2016, IDT, ISO 19353:2015, IDT) Безпечність машин. Запобігання пожежі та протипожежний захист. 


\section{REFERENCES}

1. Zakon Ukrainy «Pro zerno ta rynok zerna v Ukraini» vid 04.07.2002 №37-IV available at : http://www.zakon.4.rada.gov.ua (in Ukrainian)

2. Elevarist.com available at : http:// elevarist.com

3. Stankevych H.N. Sovremennoe sostoianye rynka zernokhranylyshch [The current state of the granaries market]. Zernovi produkty i kombikormy. -2010 . - vol.3. - pp. 34-40. (in Russian)

4. «Metodika identifikatsiï potentsiyno nebezpechnikh ob'€ktiv» [ Methods of identifying of potentially dangerous objects] nakaz № 98 vid 23.02.2006 r. Ministerstva Ukraïni z pitan' NS ta u spravakh zakhistu naselennya vid naslidkiv Chornobil's'koï katastrofi. (in Ukranian)

5. Vzryvy na elevatorakh i v skladakh napol'nogo khraneniya zerna [Explosions in elevators and warehouses for floor storage of grains] available at https://loretest.com/blog/2018/11/07/.(in Russian)

6. Statystyka pozhezh ta yikh naslidkiv v Ukraini za 20132016 roky: Statystychnyi zbirnyk analitychnykh materialiv Statistics of fires and their consequences in Ukraine for 2013-2016: Statistical collection of analytical materials](2018). K.:UkrNDICZ, 100 p. (in Ukrainian)

7. Stretovych O.A. (2016) Tendentsii roboty zernopererobnykh pidpryiemstv Ukrainy [Work trends of grain processing enterprises of Ukraine] Ekonomika kharchovoi promyslovosti. vol. 8, no. 4, pp. 46-50. (in Ukrainian)

8. Kolodiichuk V.A. (2014) Haluzeve pozytsionuvannia zernoproduktovoho pidkompleksu APK Ukrainy [Sectoral positioning of grain products of the subcomplex of agrarian and industrial complex of Ukraine]. Ekonomichnyi chasopys - KhKhI. vol. 9-10 (1), pp. 45-48. (in Ukrainian)

9. Zatserklianyi M.M. (2001) Utvorennia pylu na pidpryiemstvakh haluzi khliboproduktiv i zmenshennia pylovydilennia [The formation of dust at the enterprises of the sphere of bread products and reduction of evacuation]. Naukovo-tekhnichnyi zhurnal «Tekhnohenno-ekolohichna bezpeka», vol 3(1), pp.16-20. (in Ukrainian)

10. Thomson N. Fire Hazards in Industry. $-2001 .-176$ p.

11. D’iakonov V.I., Kusov O.V., Fesenko H.V., Bilym P.A., Myronovych V.V. (2014) Otsinka pozhezhnoho ryzyku dlia sporud vyrobnychoho pryznachennia [Assessment of fire risk for facilities of production purpose]. Visnyk Kharkivskoho natsionalnoho tekhnichnoho universytetu silskoho hospodarstva im. P. Vasylenka, vol. 148, pp. 514519. (in Ukrainian)

12. Hulida E.M., Movchan I.O.(2012) Otsinka pozhezhnoho ryzyku dlia sporud vyrobnychoho pryznachennia [Assessment of fire risk for facilities of production purpose]. Naukovyi visnyk LNTU Ukrainy, vol. 22.9, pp. 118-128. (in Ukrainian)

13. Movchan I.O, Hulida E.M. (2012) Vybir modeli vyznachennia pozhezhnoho ryzyku dlia obiektiv hospodariuvannia [Vybir modeli vyznachennia pozhezhnoho ryzyku dlia obiektiv hospodariuvannia]. Naukovyi visnyk LNTU Ukrainy,vol. 22.13, pp. 364-370. (in Ukrainian)

14. Iemelianenko S.O., Kuzyk A.D. (2011) Ryzyk yak kharakterystyka stanu pozhezhnoi bezpeky [Risk as a characteristic of the state of fire safety]. Pozhezhna bezpeka,. Lviv, LDU BZhD,vol. 18, pp.101-106. (in Ukrainian)

15. Vogman A.P., Khryukin A.V. Pozharnaya opasnost' otlozheniy na oborudovanii, $\mathrm{v}$ ventilyatsionnykh sistemakh i mestnykh otosakh ob"ektov pererabotki i khraneniya materialov rastitel'nogo proiskhozhdeniya [Fire hazard of deposits in equipment, in ventilation systems and local ventilations of objects of processing and storage of materials of vegetable origin]. Available at: https://cyberleninka.ru/article/n/pozharnaya-opasnost- otlozheniy-na-oborudovanii-v-ventilyatsionnyh-sistemahi-mestnyh-otsosah-obektov-pererabotki-i-hraneniyamaterialov-1 (in Russian)

16. Azarov V.N., Kolesnikov V.G. (2003) Otsenka vzryvopozharoopasnosti predpriyatiy po khraneniyu i pererabotke zerna [Estimation of fire explosion hazard of enterprises for storage and processing of grain] Pozharovzryvobezopasnost', vol.1,pp. 51-53.

17. Razin'kov I.V. Spetsificheskie faktory pozharnykh riskov na predpriyatiyakh pishchevoy promyshlennosti Voronezhskoy oblasti [Specific factors of fire risks at the enterprises of food industry of the Voronezh region]. Available at :https://cyberleninka.ru/article/n/ /spetsificheskie-faktory-pozharnyh-riskov-napredpriyatiyah-pischevoy-promyshlennosti-voronezhskoyoblasti

18. Punkov S.P., Kim L.V., Feydengol'd V.B. (1996) Proektirovanie elevatorov i khlebopriemnykh predpriyatiy s osnovami SAPR [Design of elevators and bread-making enterprises with SAPR basics] Voronezh: Izdatel'stvo Voronezhskogo universiteta, 284 p. .(in Russian)

19. Fesenko O.O., Lysiuk V.M.(2017) Problemy pozhezhnoi bezpeky zernosusharok [Problems of fire safety of grain dryers] Proceedings of the VII Vseukrainskoi naukovopraktychnoi konferentsii $\mathrm{z}$ mizhnarodnoiu uchastiu «Nadzvychaini sytuatsii: bezpeka ta zakhyst». - Cherkasy, ChIPB im. Heroiv Chornobylia , pp. 73-74. . (in Ukrainian)

20. Volkov V.E. (2011) Sistema podderzhki prinyatiya resheniy po voprosam vzryvobezopasnosti silosov i silosnikh korpusov zernovykh i zernopererabatyvayushchikh predpriyatiy [System of support of decision-making on questions of explosion safety of silos and silos corps of grain and grain-processing enterprises], Avtomatika, L'viv,pp. 335-336, available at : http:// ena.lp.edu.ua (in Russian)

21. Teplov A.F.(1990) Okhrana truda v otryasli khleboproduktov [Labor protection in the bread industry]. M, Agropromizdat, 255 p. (in Russian)

22. Perelik nebezpechnykh rechovyn [List of hazardous substances]. available at :http://www.eco.ck.ua/ docs/Perelik\%20rechovyn,\%20klas\%20nebezpeky.doc

23. Hulida E.M.(2016) Vplyv pozhezhnoho ryzyku na velychynu zbytkiv vil pozhezhi $\mathrm{v}$ prymishchenniakh riznykh obiektiv [Influence of fire risk on the amount of damage from fire in premises of various objects]. Pozhezhna bezpeka: zbirnyk naukovykh prats LDU BZhD, vol.28, pp. 36-42. . (in Ukrainian)

24. Biehun V.V. (2004) Bezpeka zhyttiediialnosti: Navchalnyi posibnyk [Life Safety: An education guidance] - K, 328 p.

25. Postanova Kabinetu Ministriv Ukrainy vid 29 liutoho 2012 r. №306. $-\mathrm{K} .-3 \mathrm{~s}$.

26. NAPB A.01.001-2014. Pravyla pozhezhnoi bezpeky v Ukraini.

27. NAPB V.01.057-2006/200. Pravyla pozhezhnoi bezpeky v ahropromyslovomu kompleksi Ukrainy.

28. Metodyka vyznachennia ryzykiv ta yikh pryiniatnykh rivniv dlia deklaruvannia bezpeky obiektiv pidvyshchenoi nebezpeky» zatverdzhena nakazom № 637 vid 4 hrudnia 2002 r. Ministerstva pratsi ta sotsialnoi polityky Ukrainy

29. GOST 12.1.005-88 «Obshchie sanitarno-gigienicheskie trebovaniya $\mathrm{k}$ vozdukhu rabochey zony»».

30. Shtokman E.A. (2001) Ventilyatsiya, konditsionirovanie i ochistka vozdukha na predpriyatiyakh pishchevoy promyshlennosti [Ventilation, air conditioning and air purification at the enterprises of food industry]. M.,ASV, $564 \mathrm{p}$.

31. ДСТУ ISO/TR 16732-3 (ISO/TR16732-3:2013, IDT) Fire safety engineering -- Fire risk assessment -- Part 3: Example of an industrial property.

32. ДСТУ EN ISO 19353 (EN ISO 19353:2016, IDT, ISO 19353:2015, IDT) Safety of machinery -- Fire prevention and fire protection. 


\section{AGRICULTURAL STORAGE ENTERPRISES: RISK OF FIRE DAMAGE}

S. Nemenushcha, Cand. of Sc. (Agriculture),O. Fesenko, V. Lysiuk, Cand.of Sc. (Eng.), associate professor

Odessa National Academy of Food Technologies, Ukraine

\section{KEYWORDS}

grain processing industry, elevators, fire and fire explosion safety, identification of places of localization, risk.

\begin{abstract}
ANNOTATION
The analysis of fire and fire explosion safety on grain elevators in Ukraine for the last 11 years has been carried out. It has been established that on grain elevators, from 2014 onwards, an increase in the number of cases of fires is observed annually. If there were 3 fires in 2014 and 2016, then in 2018 there were already 15. In just 2 months of 2019, four such emergencies were created on elevators. The localization places of the risk of fires and explosions at enterprises have been identified. Localization of fires occurred in $56.8 \%$ of cases in grain dryers. In the second place there are fires in warehouses $-18.2 \%$. The same number of fires, by $4.5 \%$ of the frequency of occurrence, is recorded in the narias, in transport galleries and at transformer substations. Occasionally, with a probability of up to $2.4 \%$ each, there were cases of fire due to lightning strike and factors of the "human factor» (violation of the technological regulations, rules of fire works, arson). An estimation of the risk of fire on grain elevators is carried out by the statistical method. It was established that the probability of fires for the last 11 years was $R=18,9 \times 10^{-4}$ in grain dryers, and in warehouses $-R=6,05 \times 10^{-4}$. The risk of fires in narias, in transport galleries and at transformer substations was estimated to be $R=1.5 \times 10^{-4}$, respectively. If the causes of the fires were a "human factor", namely the violation of the technological regulations, rules for conducting fire works and as a result of arson, then each time the risk was $R=7.5 \times 10^{-5}$. In order to provide fire and fire explosion safety on elevators it is proposed: to replace, reconstruct or re-equip technological equipment, machines, mechanisms, etc.; to check the availability of developed technical projects, technological regulations, other technical documentation for high-risk works, equipment, tools, protective devices of dangerous zones of machines and mechanisms, starting, preventive, brake and cleaning devices, systems of blocking and signaling, ventilation and illumination, safety signs, primary means of fire extinguishing, holding at the enterprises of certification of buildings, structures, engineering networks etc.
\end{abstract}

\section{ПРЕДПРИЯТИЯ ПО ХРАНЕНИЮ ЗЕРНА: РИСК ВОЗНИКНОВЕНИЯ ПОЖАРОВ}

С.Н. Неменущая канд. с.-х. наук, Е.А. Фесенко, В.Н. Лысюк, канд. техн. наук, доцент, Одесская национальная академия пищевых технологий, Украина

\section{КЛЮЧЕВЫЕ СЛОВА}

зерноперерабатывающая отрасль элеваторы, пожарная и взрывопожарная безопасность, идентификация мест локализации пожаров, риск.

\section{АННОТАЦИЯ}

В работе проведен анализ пожарной и взрывопожарной безопасности на зерновых элеваторах в Украине за последние 11 лет. Установлено, что на зерновых элеваторах начиная с 2014 года ежегодно наблюдается увеличение количества случаев возникновения пожаров. Если в 2014 и 2016 годах зафиксировано 3 пожара, то в 2018 году возникло уже 15. Только за 2 месяца 2019 образовалось 4 таких чрезвычайных ситуаций на элеваторах. Идентифицировано места локализации риска возникновения пожаров и взрывов на предприятиях. Локализация пожаров происходила в 56,8\% случаях в зерновых сушилках. На втором месте фригурируют пожары на складах - 18,2\%. Одинаковое количество пожаров, по 4,5\% от общего количества, зафиксировано в нориях, на транспортных галереях и на трансформаторных подстанциях. Иногда, с вероятностью до 2,4\% каждый, встречались случаи возгорания в результате удара молнии и происшествий с учетом «человеческого фрактора» (нарушение технологического регламента, правил проведения огневых работ, поджога). Проведена оценка риска возникновения пожаров на зерновых элеваторах статистическим методом. Установлено, что вероятность пожаров за последние 11 лет составила $\mathrm{R}=18,9 \times 10^{-4}$ на зерносушилках, а в складах $-\mathrm{R}=6,05 \times 10^{-4}$. Риск возникновения пожаров в нориях, на транспортных галереях и на трансформаторных подстанциях оценивался соответственно по 
$\mathrm{R}=1,5 \times 10^{-4}$. Если причинами возникновения пожаров был «человеческий фрактор», а именно нарушение технологического регламента, правил проведения огневых работ и в результате поджога, то каждый раз риск составлял $\mathrm{R}=7,5 \times 10^{-5}$. C целью обеспечения пожарной и взрывопожарной безопасности на элеваторах предлагается: проводить замену, реконструкцию или переоснащение технологического оборудования, машин, механизмов; проверять наличие разработанных технических проектов, технологических регламентов, другой технической документации для работ повышенной опасности, исправности оборудования, инструмента, защитных устройств опасных зон машин и механизмов, пусковых, предохранительных, тормозных и очистных устройств, систем блокировки и сигнализации, вентиляции и освещения, знаков безопасности, первичных средств пожаротушения, проведение на предприятиях паспортизации зданий, сооружений, инженерных сетей и другие мероприятия. 